\title{
Pre-Truth Life in Post-Truth Times
}

\section{Abstract}

This article could be characterised as providing philosophical preliminaries for a diagnosis of the contemporary 'post-truth'-problematic. I argue that claims to truth in public discourse and collective life generally are systematically and unavoidably ambivalent, so that truth cannot ultimately be disentangled from untruth. Truth becomes a problem in this sense where matters are morally-existentially charged, and so self-deception becomes tempting, individually and collectively. To the extent that our life is marked by injustice and destructiveness, it is necessarily also marked by systematic falsification, a conspiracy to deny the truth about it, about us. I argue that collective life exhibits pervasive hostility to interpersonal (moral) understanding, which is repressed through collectively established fake 'understandings' and regimes of respectability. The fact/opinion and fact/value distinctions function as defences against understanding, while meaning and truth become things to be determined rather than understood, and the concept of representability - how things can be made to appear - becomes central. However, standard philosophical views on truth, meaning and morality render the problematic sketched here invisible, because they effectively move wholly within the collective perspective that needs to be problematised - as Wittgenstein (arguably) realised.

The concept 'post-truth' suggests a potentially alarming shift in the public mood of Western democracies, tied to shifting distributions of power and authority between various social groups and institutions, with corresponding changes in public discourse. Tracing these changes is necessary for understanding the contemporary socio-political situation, and I'll say something about this below. However, grasping 
the contemporary constellation of problems presupposes clarity regarding the background against which it arises, and my central concern will be to say some things about this; about how 'truth' functions in public discourse not just today, but generally - things usually ignored, indeed repressed, in philosophy and everyday thinking. (As I'll indicate, Wittgenstein had a keen sense for them, although this isn't commonly appreciated.) The main point is that, in the public discourse in which collective life gives voice to itself, from gossip and crude expressions of opinion and feeling to sophisticated political, scientific and philosophical debates - and in the private thoughts that are the echo in us of this public talk - truth is both an absolutely crucial and an inherently unstable, self-obfuscating and self-undermining notion. There was no time before 'post-truth' when the nature and importance of truth was clear, because in collective terms that was never and never will be clear, and any warnings about the contemporary threat to 'rational culture' will be correspondingly unclear. In an important sense, 'rationality' and 'truth' appear, collectively and publicly speaking, only against a background of pervasive untruth and confusion. In this sense, Bob Dylan was right: "All the truth in the world adds up to one big lie". ${ }^{1}$ The whole point, however, is to recognise what the collective 'world' constitutes itself against.

\section{Truth as a problem: the ubiquity of self-deception}

Clearly, applying the concept 'truth' is often unproblematic; in countless practical and intellectual, everyday and scientific contexts, there's no doubt about the facts or how to establish them, or about the correct conclusions to draw, even if crackpots and incompetents insist otherwise. However, referring to everyday contexts where 'truth' is unproblematic is irrelevant for understanding 'post-truth' just because the contexts are unproblematic, for the question is precisely how 'truth' can become a problem, an object of aversion or disdain, to the point of people denying that there's any such thing as 'truth'. ${ }^{2}$ No one has a

\footnotetext{
${ }^{1}$ A line from Dylan's song “Things have changed".

2 Wittgenstein underlines this general methodological point. "[T] here is no common sense answer to a philosophical problem"; what must be understood is the attraction of the confused philosophical problematisation, "the temptation [...] the source of [the] puzzlement" (BB: 589; cf. Backström 2011 and 2013).
} 
problem with admitting simple facts or truths just as such, and therefore it is useless to demand, as many citizens concerned about the spread of the 'post-truth' mood now do, a reinstatement of the respect for facts and the fact-establishing sciences just like that. Admitting facts becomes a problem, and denying them tempting, only when people feel that this would somehow threaten them. However, we must distinguish between two kinds of threats, corresponding to two kinds of resistance to truth. Sometimes, people lie simply because they realise that admitting certain facts publicly would threaten their material interests or positions of social power. This kind of situation is uninteresting for our discussion, insofar as it presupposes a (more or less) clear sense of what the truth is. The interesting situations are of a different kind, where the perceived threat is 'existential' rather than 'external'. That is, here people feel, more or less instinctively and acutely, that admitting how things stand would threaten their image of themselves and of their relation to others, would make them feel guilty, ashamed, contemptible, disgusting, abandoned and alone, make their life feel empty and meaningless, etc.

Much could be said about the connections and differences between these various characterisations (shame and abandonment, say); this would show concretely what the difficulties with truthfulness in relation to oneself and others are. Here, I simply emphasise that acknowledging truths becomes unbearable - there is anything to acknowledge, as opposed to simply register - only when doing so is connected to charges of this moral-existential kind. These charges are certainly often tied to 'external' interests and threats, but they aren't reducible to or derivable from them. The fear of losing money, say, may be seen as a merely 'external' threat, to be noted and duly defended against. However, people invest - to use this appropriately ambiguous term - money with all kinds of existential meanings; having money measures success, social approval, hence its loss directly threatens loss of self-respect ("I'm a poor loser, a failure"), for example. Insofar as these kinds of 'investment' are in place, this means that people's view of their own relation to money and what they're prepared to do for money won't be dispassionate, 'purely economic'. In the sequel, all kinds of plain facts about the economic system in which we're entangled and 'invested' will become contested. That is, they become not hard to know 
but hard to take, to admit, and this difficulty will stretch all the way from the shopper's desire and anxiety-laden thoughts to seemingly dispassionate academic theorisations in economics. ${ }^{3}$

In self-deception one refuses to acknowledge how things stand and misrepresents them in a comforting or flattering light; sentimental, cynical, heroic, tragic, etc. And this generally includes lying and misrepresenting things to others, too, since one needs their help in upholding one's false self-representation which, furthermore, is basically about one's relation to others. Think, e.g., of how someone's self-pitying and self-exonerating view of their family problems usually includes talking to friends with the insistent but generally unspoken demand that they affirm one's false account of the situation; questioning it would be 'heartless' and 'disloyal'. Having one's lies affirmed by others is necessary as part of hiding the truth from oneself. Psychosis might be defined as the limit case where, as far as possible, one dispenses with the conspiratorial cooperation of others and opts for a world of private delusion, instead of the collectively upheld delusions through which 'normal' people 'deal' with (i.e., deny) their existential problems. The aim in both cases is the same: repression, the self-deceptive numbing and blurring of one's own sense and understanding of what one's relation to self and other actually is.

Facts and truths, then, are difficult to admit only where doing so is morally-existentially charged. Then, self-deception becomes tempting. In fact, unwillingness to see the difficulty clearly is an essential aspect of moral-existential difficulties. There's no such thing as acknowledging destructiveness, evil, in oneself truthfully, without evasion or falsification, and to still go on indulging it. For example, there's no such thing as a truthful coward or a truthful but unjust person. If one doesn't find it in oneself to be courageous and just one must deny one's own cowardice and injustice; one claims to have acted sensibly, not cowardly, for example. Sometimes, one may say the words "I'm such a coward" or "I know that wasn't fair", but only in a tone which signals refusal to fully acknowledge one's injustice or cowardice. One admits to being a coward, but as though this was merely a

\footnotetext{
3 Some of the deep and systematic problems in standard economic theorising are discussed, from very different perspectives, in McMurtry 1999, Rowbotham 2009, Shaikh 2016, and Yuran 2014.
} 
regrettable psychological fact about oneself ("I've always been shy of confrontations"), or as though just admitting it would somehow exonerate one, and so one doesn't really acknowledge one's cowardice after all; that one deliberately chooses to save one's own skin even if it means letting someone else down. Or one admits that what one did wasn't quite fair, but with the implied addendum: “... but that's how things work, this world isn't a fair place", or "... but let's not make a fuss about following every rule slavishly", etc. In one way or other, one disavows one's own injustice: that one deliberately wronged someone because it suited oneself better. The point here is neither merely psychological, nor merely logical or formal; it is about meaning, about understanding what it means to care about another person; what good and evil are. Insofar as one can 'admit' to evil in oneself without changing, without fighting the evil, this shows that one doesn't really admit what one seems to admit; instead, one keeps the full meaning of one's own words at arm's length, because opening oneself to it would mean opening oneself to the other person, and one feels that this would bring them 'too close'. The temptation to selfdeception/repression is partly defining of moral, as opposed to merely intellectual or practical difficulties, yet standard ethics is premised on ignoring this crucial point, on treating self-deception as merely a psychological curiosity. ${ }^{4}$

My discussion so far might seem like a digression into individual moral psychology without relevance for the question of 'post truth', which relates rather to social/collective psychology, to the authoritative status of 'truth', 'facts', etc., bestowed (or not) by the community. But communities are as incapable as individuals of fully acknowledging the evil they do. That is, when individuals speak and act

\footnotetext{
${ }^{4}$ But even if repression is often involved in evil-doing, couldn't there also be evil without repression/self-deception; isn't that 'logically possible'? I don't think one can really make sense of this suggestion. Instead of trying to 'prove' this, however, I would ask why demanding 'proof of this should be the response to being reminded of the pervasiveness of selfdeception/repression in actual moral difficulties, and its striking absence in philosophical accounts of ethics? Why not consider, instead, the possible motives for the neglect of selfdeception and explore the implications of taking it seriously? Is that perhaps something one would rather not do? - I note, parenthetically, that Freud's discussions of repression (surveyed in Boag 2012) are inadequate precisely because he overlooks that what one ultimately represses is one's own moral understanding (conscience); "We cannot do evil ... and know it. We fashion the unconscious so as not to know it" (Symington 2004: 70; cf. Backström 2019, Nykänen 2009).
} 
in the name of their community, they don't magically become capable of simply ignoring conscience; they still need to 'justify' themselves, i.e., to deny the evil in their actions. Hence, killing in war isn't considered murder, but an act of justified collective self-defence, and all wars are, so both parties claim, wars of self-defence started by the other side's aggression - just as all private quarrels were, apparently, started by the obstinacy of the other person. Or, if the aggression is admitted to, it is presented as a 'sad necessity', perhaps a 'law of nature', that communities make war on each other, that the weak perish and the strong take what they want - which implies that this isn't about choices and callousness at all and that there can be no moral objection; witness the Athenians' speech to the Melians they proceed to massacre (Thucydides 2008: V.84-116). Again, this isn't just a socialpsychological generalisation about what mostly happens. It is part of what it means for a community to engage in collective evil, whether external or internal violence, exploitation and oppression, that the community will, in its official self-understanding, disavow this evil. Just as there's no such thing as a truthful coward, there's no such thing as a community that is truthful about its own iniquities; about, say, the exploitation of the poor, the racism, the sexualised oppression and cruelty to animals that its way of life incorporates. It isn't possible to be truthful about the evil one is doing; that is possible only in repentance, when one has stopped the evil. And with regard to the question of truth, this means that insofar as individual and collective evil abounds in the world, untruth, denial and misrepresentation of reality, also abound - which means, further, that whatever dignity is accorded to 'truth' and to the 'respect for facts' will take place against a pervasive background of untruth.

For instance, classical liberal journalism insists religiously on observing accuracy and fairness in reporting, i.e., it insists on a particular kind of strict truthfulness. Nonetheless, it can live up to these standards and still not seriously rock the boat in terms of the balance of power in societies which are in many ways extremely unjust and exploitative, where masses of people work for starvation wages to keep a few living in luxury, etc. This very fact shows the limitation of the concept of 'reporting the truth' at stake. Details about the injustice and exploitation may be accurately reported, yet the whole structure of 
injustice and exploitation stays in place and is perceived as generally legitimate; the big lie the structure presupposes isn't challenged by the small truths the reports reveal. Even if the news aren't fake, the unjust life within which they are reported is pervaded and perverted by what might be called fake intelligibility or fake sense; a web of misrepresentations which functions to hide its iniquity.

In this sense, we don't live in a post-truth world but in a pre-truth world. However, the pre-truth world is always already a post-truth world, insofar as there's no mere absence of truth. Rather, truth, a moral sense and understanding of what one is really doing and what's going on between us, on the individual and collective level, is repressed. It isn't that one just hasn't yet arrived at truth, but that one actively tries to keep it away. This manifests itself as all kinds of stupidity and failures of understanding, but the root-problem isn't intellectual. "What makes a subject hard to understand - if it's something significant and important" is rather, as Wittgenstein says, "the contrast between understanding the subject and what most people want to see. Because of this the very things which are most obvious may become the hardest of all to understand" (CV: 17; cf. PO: 161). Only insofar as people are just and good, insofar as they don't fear each other and disgust themselves, but long wholeheartedly to know each other and themselves, can truth in the full sense be lived and spoken between them (Wittgenstein: "The truth [cannot] be spoken [...] by someone who still lives in falsehood", CV: 35). How far truth can, or rather will be spoken between individual people must be discovered by these people themselves, by 'me' in relation to 'you'. A 'truthful society' would be a society in which each member is truthful in their relation to each other. But there's no such thing as a truthful society considered as a collective, a group tied together by certain norms, values and practices, for, as I'll try to explain, the depersonalisation involved in the very constitution of collective normativity implies a repression of interpersonal I-you-truthfulness; a repression carried out partly 
through the installation of an essentially ambivalent, public (depersonalised) conception of 'truth'.

\section{Conspiratorial 'understandings' and respectable society's hostility to understanding}

When 'post-truth' is discussed in the respectable media, the focus is typically on how populist politicians and other 'post-truthers' seem not to care that no credible evidence for their claims can be produced, or that decisive evidence against them is produced. However, this indifference to truth in the sense of factual correctness of details is motivated by an appeal to a stronger notion of truth. For those who present them, 'alternative facts' aren't flights of fancy but elements of the true view of what is going on; a truth that has, supposedly, been systematically denied by the mainstream media controlled by various elites in these elites' interest. So the 'post-truthers', at least the typical populist politicians, claim to be the ones who care about the truth and tell it to 'the people' who've been lied to for too long. ${ }^{5}$

The idea of a conspiracy by the elites to fool the people has always been a mainstay of both populist and totalitarian movements (cf. Arendt 1973: 326-64). While conspiracy-theories often take inane particular forms - Freemasons, Jews or Aliens control the world - they feed on an undeniable and uncomfortable truth. For, as indicated above, insofar as society is unjust and oppressive, the iniquity and oppression must be made to appear basically acceptable and legitimate to its members, otherwise the social order would be overthrown. Those on top need to enjoy their privileges with a 'good conscience' and those on the bottom need to view their situation as their own fault, or as simply 'natural'; "Every established order tends to produce $[\ldots]$ the naturalization of its own arbitrariness" (Bourdieu 1977: 164). And the perspective from which the mainstream media generally presents

\footnotetext{
${ }^{5}$ Similarly, the cynic who 'believes in nothing' advertises, in his very debunking of 'idealistic pretensions', a moral uprightness and commitment to truth that the 'cowardly idealists' lack; he alone has the courage to admit that 'in the end, it's all just about... (money, sex, power, etc.)'. The passion and the very possibility of cynicism hangs on this single, self-deceptively selfundermining point: the one thing the cynic won't do for money is (so he tells himself) lie to himself and pretend that there are things money cannot buy. - The third essay in Nietzsche (1956) is devoted to this paradoxical predicament of the 'cynical believer in truth'; Nietzsche doesn't analyse it from the outside but rather speaks desperately and confusedly out of it.
} 
things must serve these purposes. In this sense, there is necessarily a media-conspiracy, including both news and cultural media more broadly (films, advertisements, etc.), to present a version of events making oppression and injustice disappear, or else appear natural and legitimate.

However, such conspiracies don't, at the basic level, operate the way conspiracy-theorists imagine, through secret meetings where elites decide on their strategies for duping the people - although such highlevel secret meetings are doubtless more widespread than respectable opinion wants to believe. But in general, the meetings aren't secret, and deliberate lies aren't the main point. Rather, in cabinets, boardrooms, and news-rooms there's a more or less spontaneous and unspoken 'understanding' between the people discussing and making decisions regarding what people want, what's true, important, realistic, respectable, vulgar or funny, and this understanding 'happens' to be such that the needed legitimisation of the status-quo of power and privilege is produced. There's seldom a need for directly lying about anything, as inconvenient facts simply aren't mentioned; direct censorship is seldom called for as inconvenient ideas for stories or programs just don't come up; there's no need to prohibit vulgar jokes in an environment where a shared sense of propriety makes everyone instinctively avoid vulgarity, etc. These remarks aren't based on any particular empirical investigation of proceedings in boardrooms or elsewhere; I'm remarking on general features of social contexts and social consensus known to everyone. They feel very different, however, depending on one's own position with regard to the group-consensus in question. If one shares and feels comfortable in it, one will notice only, say, 'that irritating Jones always bringing up the same irrelevant objections and wasting everybody's time'; if one is Jones, one may feel a compact refusal and hostility to consider a crucial objection.

The situation, then, is worse than conspiracy theorists present it, and less flattering to us, 'the people'. The conspiracy, generally speaking, isn't secret and we aren't its innocent victims; it is rather one in which we all (more or less) partake, quite publicly. When we consume highly ideological news and films without noticing anything untoward, simply finding them entertaining or informative (and here the word 'consumer' is quite appropriate), we're as much part of the 
conspiracy of 'understanding' as the producers. I put 'understanding' in scare-quotes, because what's shared here isn't, as such, real understanding; it isn't expressive of anyone making truthful efforts to think things through, to grasp the moral import of things and what one can honestly understand. On the contrary, collective climates of opinion are formed, and change, precisely through the individuals involved not thinking anything through and refusing to be independent in relation to the collective. People 'acclimatise', fall in with how those around them speak. As the great analyst of Nazi propaganda Victor Klemperer notes, the common language starts to "think for me" and "increasingly dictates my feelings and governs my entire spiritual being the more unquestioningly and unconsciously I abandon myself to it" (2006: 15). The crucial point is that this isn't unavoidable; everything depends on how far I abandon myself to collective modes of speaking, thinking and feeling, or rather struggle to be free of them. In my view, this is the central struggle in life and philosophy; the struggle to discern the difference between understanding and 'understanding', between genuine intelligibility and fake intelligibility, between what really does and doesn't make sense and what seems, because it is collectively taken to make sense or not.

One of the central modes of upholding collective fake intelligibility is the idea of the respectable. This is just what populist politicians like Trump attack: they don't ridicule truth as such but the 'truth' transmitted by the respectable media, and they excel in turns of speech that the respectable deem vulgar and unserious. Respect is tied to authority, and the post-truth phenomenon could roughly be described as a crisis in the authority of existing institutions. This doesn't mean that people no longer care about truth as they used to, for 'respect for authority' itself isn't a concern for truthfulness, but the very opposite; a concern with who is given, and that someone should have, the social 'right' to pronounce things 'unquestionably true' or, on the contrary, 'beyond the pale'. ${ }^{6}$ Authority is, at bottom, simply the power of social consensus, i.e., social pressure, symbolically dressed up in dignified robes. And, in general, nothing is as literal as the symbolic; think of the robes of the priest or the judge, and of the concretely respectful attitude

${ }^{6}$ Authority is thus directly related to the idea of the sacred (cf. Ellul 1975). 
(no running or shouting, etc.) assumed when entering a church or a court.

This dignification through symbolisation and institutionalisation distinguishes the rule of law from mob rule, the naked rule of grouppower. Mob rule is as powerful as the rule of law, and also as dependent on presenting itself as 'justified'. One couldn't imagine a more striking image of people absolutely convinced of the righteousness of their cause than a lynch-mob - and this intensity of conviction, i.e., the determined refusal to listen to objections, even to the point of murder, is proportionate to the depth of the repression of conscience, which happens precisely through the depersonalisation in 'merging with' and 'losing oneself' in the mob, thus losing one's sense of responsibility for and connection to the victim. ${ }^{7}$ The important difference between mobrule and the rule of law, i.e., the respectable rule of authority, isn't obviated by the fact that they share a common essence. Because mob rule isn't institutionalised, stabilised by permanent institutions and rules, the ever-changing moods of the collective - which can go from sentimental sympathy to lynching in an instant - determine what happens at any given moment. ${ }^{8}$ The good aspect of the rule of law, and the aspect exclusively focused on in standard accounts, is its function as bulwark against mob-emotion; e.g., the police and courts prevent lynching and ensure that justice is done in an orderly fashion, according to set rules. But the law and other forms of institutionalisation have a Janus face; if they protect against outbursts of mob-violence, they can also give injustice permanent form, make it respectable (cf. Jim Crow laws). And from the point of respectability and authority themselves, there's obviously no telling whether the things they hallow are actually just or unjust, good or evil. Respectability is a regime of seeming, of fake intelligibility; what it presents as being-so is, from its own perspective, how it is.

Because respectability/authority is all about appearances, the respectable are essentially defenceless against the attack mounted by

\footnotetext{
${ }^{7}$ Cf. Backström and Nykänen 2016a, and on scapegoating, Girard 2001.

${ }^{8}$ The ending scene of Kubrick's Paths of Glory - the girl singing to a mob of soldiers - brilliantly depicts the sudden change from destructive to sympathetic group-moods (and vice versa); another classic singing-scene, the Nazi boy in Bob Fosse's Cabaret, shows not the sudden change from one emotion to another, but rather the gradual 'change of aspect', from idyllic to murderous, of collective emotionality.
} 
vulgar populists. The regime of respectability consists in the tendency of people to respect certain limits, institutions and people; as long as the respect is there, it appears inviolable, but once violated, its defenders can only wave their arms in ineffectual outrage. ${ }^{9}$ Furthermore, there's a secret agreement between the respectable and their vulgar attackers, giving the vulgar the upper hand. Norms of respectability - 'political correctness' is their current liberal form, but every social order has its own - proscribe and prescribe the expression of certain views and the use of certain words. Understanding isn't at issue, or is rather repressed by the norms, which simply outlaw certain views and attitudes so that they cannot even be discussed. For example, to remain respectable today, one mustn't even utter 'the N-word'; very politically correct people may be so sensitive on this point that they literally feel unable to stay in the room with anyone who utters it (I've witnessed this). The violence of such reactions shows the enormous charge surrounding, in this case, attitudes to racial issues, and this means - since the 'issue' isn't some abstraction but the way people relate to each other - that one is unable to relate to others without thinking about, constantly being implicitly aware of, their and one's own 'racial identity'. And this is where the aforementioned secret agreement lies, for the politically correct liberal is as obsessed with race, as incapable of meeting a person without immediately categorising them as 'white' or 'black' etc., as the most vulgar racist, only the liberals have decided that this fact mustn't be mentioned, that all the words that have served to express this obsession in the past are to be outlawed and replaced by a new lexicon of race whose paradoxical function is to signal that its respectable users would never treat anyone differently based on their race - as though obsessing about their race, if only to 'treat them respectfully', wouldn't already be a way of treating people 'differently', and as though there could be good forms of obsessing about 'characteristics' marking individuals as 'belonging' to particular groups. ${ }^{10}$

Now the vulgar racist uses this secret agreement for his own ends; in his mind, the (correct) observation that respectable liberals are as

\footnotetext{
9 Think, also, of the fall of dictators like Ceauşescu. When people had finally 'had enough' and turned against him, he couldn't do anything, for his formerly seemingly absolute power rested solely on people's tendency to grant it to him.

10 The 'unconscious racism' of liberals who in their actions discriminate against people they officially claim to have nothing against shows their racism too, but my point is that the very
} 
obsessed with race as he is 'proves' that 'deep down we're all racists', with him simply being more 'honest' because he frankly says what the liberal too thinks. But the fact that racism has many surface-forms doesn't mean that it is 'natural' or 'unavoidable', or that one should frankly affirm one's racism; it simply means that vulgar racists and respectable hypocrites basically share the same destructive and morally deplorable attitude. One should neither frankly assert it nor hypocritically deny it, but rid oneself of it. This, however, demands precisely the challenging thing that both vulgar racism and respectability are ways of avoiding and refusing, namely the work of understanding oneself in one's concrete relation to others, of opening up to the people one meets, be they black or white or whatever. No norms can solve the difficulty of the personal encounter for us; rather, we use norms to repress it, for example by outlawing any words that may cause offense and so, perhaps, prompt a confrontation with the other in which one wouldn't know what to say because one would actually have to say something to them, try to reach them instead of parroting polite formulas. - I'm not suggesting we discard politically correct norms or norms of respectability more generally; that would demand a society of truly free and open, fearless and humble people. I'm rather pointing to the character of the difficulties that make us feel a need for such norms, and to why they by themselves won't solve these difficulties, but rather make them harder to discuss truthfully. And this holds even though we may not generally be able to manage, to keep social intercourse even half-decent, without such norms.

Our felt need for respectability is one manifestation of the deep, fearful hostility to understanding, i.e., to truthful relations with self and others, that pervades everyday life. This hostility appears in countless forms, of which the self-deception-in-outright-evildoing is only the most dramatic. Think, for instance, of the eagerness with which people often keep their thoughts and conversations to plainly practical, technical and factual matters, i.e., matters where there is really nothing to understand. People talk about the prices of things, the weather, sports-results; they detail what they've been doing and how they've

obsession with race is itself already racist. And note that all racism is 'unconscious' in the sense that even the most outspoken racists will deny the evil confusion in their view; they will present it as the simple truth about the 'others' ("Trust me, I know what Russians are like"). 
been feeling in the spirit of external enumeration ("I visited $A$, then went to B, then had a bit of flu..."), etc. Of course, there's sometimes real practical point in such talk, but people talk this way endlessly where there's no point - other than the defensive one of keeping conversation going without opening up any questions which would call on oneself to respond in a personal way. The same tendency is manifest in the obsessive focus, in much of the human sciences, on finding out facts to the virtual exclusion of trying to understand their meaning; consider, e.g., the disproportion in standard papers in experimental psychology between the great effort put into experimental design and statistical analyses of results, and the typically incredibly thin and trivial 'discussions' (so-called) of their significance. The ultimate of this attitude is the fantasy that machine-collected and computed 'big data' will finally allow us to predict and manipulate without having to understand anything at all: "Who knows why people do what they do? The point is they do it, and [...] with enough data, the numbers speak for themselves" (Anderson 2008). In the humanities, 'exegesis' often plays the same defensive role as the focus on fact-gathering; thus, academic philosophers have largely reduced Wittgenstein's writings to an object of scholarly study of 'what Wittgenstein said', thereby sabotaging Wittgenstein's hope to "stimulate someone to thoughts of his own" (PI: Preface). And the other side of the same hostility to thinking for oneself is the regular upsurge of wildly speculative theorising; here, one keeps understanding away not by obsessively running after ever new facts or 'readings', but by losing oneself in the cloud-cuckoo-land of speculative fantasy.

Another example of the hostility to understanding is the tendency to assume - unsurprisingly, given how lifeless thinking becomes in most academic and other settings deformed by this very hostility - that enjoying oneself, 'living a little', is somehow antithetical to thought and understanding; hence, entertainment is generally more or less idiotic, and 'having fun' often means intoxicating oneself, blurring and numbing one's understanding, one's sense of oneself and the other. Polite conversation, a variant of respectable discourse, offers yet another example. Thus, one politely asks the guests whether they liked the food and is pleased when they say yes, although one knows that if they disliked it they wouldn't say so; doing that would cause annoyance 
and offence ("I prepare food for them, and this is how they thank me!"). What makes questions part of polite conversation is precisely that while they formally ask for truthful answers, their tone, the whole 'atmosphere' in which they're asked, implies that the answer must be 'positive', not upsetting or challenging. Thus polite conversation is like advertising; in both cases, one willingly allows oneself to be manipulated by communication that aims at producing 'positive perceptions' and 'good feelings' in one regarding the speaker, oneself and the thing spoken about, typically all at once. The question of truth and even sense is effectively bracketed. No one really thinks that happiness and beautiful friendships have any connection with particular brands of soft-drink, say, yet the main function of advertising is to imply non-existent connections of this kind. And it 'works', of course, because the audience is tempted by fantasies of this kind; that is, the soft-drink becomes a prop around which one can organise one's daydreams of being beautiful and popular. No doubt, my critical remarks on politeness will provoke the objection that one surely wouldn't want to be around people who always said what they actually think, not caring about consideration and sparing others' feelings! Well, that's just my point: the fact that we tend so easily and so vehemently to respond like this reveals our hostility to truthful relations. We instinctively think that being truthful would be terrible, and that people who were would have to be some kind of unfeeling monsters, as though caring about others would self-evidently mean manipulating and lying to them to keep them 'happy'. Of course, polite and considerate people don't want to talk about lying and manipulation; that would be inconsiderate and hurtful. And that, again, is part of the problem, part of how politeness works: by presenting what from the perspective of a longing for truthful contact is manipulation and lying as something else, something good.

\section{Opinions and values as defensive postures}

"It used to be", Stephen Colbert says, that "everyone was entitled to their own opinion, but not their own facts. But that's not the case anymore. Facts matter not at all. Perception is everything" (Rabin 2006). Insisting on the classical distinction between 'facts' and 'opinions' (or 'values', 'feelings', 'personal beliefs' etc.) won't save us 
from 'post-truth', however. On the contrary, the latter is a natural outcome, indeed an unspoken presupposition, of the perspective built around that distinction. Similarly, bringing in the question of 'entitlement' leads directly to post-truth, for it presupposes the rootconfusion that truth and meaning are, basically, something to be determined by someone, and then the question would be only who is 'entitled' to determine them. This is the language of public discourse, of power and authority; the very language used to shout and shut understanding down, replacing it with 'understanding'.

Obviously, opinions are often unproblematic. In many practical, political and aesthetic contexts well-intentioned and well-informed people weigh evidence and relevant considerations differently, thus forming different opinions about the matter. But, again, the unproblematic cases are irrelevant to the problematic of 'post-truth', as to any other philosophical problem. What we should consider is rather what happens when people start insisting on their 'entitlement' to their opinions, and, relatedly, what it means when the distinction between facts and opinions/values is turned - as is characteristic of modern culture - into a metaphysical picture, a general schema for framing questions about understanding and truth. That schema ignores and excludes precisely the dimension of understanding in which our difficulties with truth actually arise, and where they must be confronted; the dimension of thinking conceived as conscientious reflection on what it means to relate truthfully to others and oneself (often, in relating to some matter at hand). In relation to objective facts, all one can rationally do is determine what they happen to be, and as for the other pole of the standard picture, people's 'subjective' opinions, values etc., they are also simply to be registered, including in one's own case, where one just asserts and 'has' them ("Whatever you say, this is my opinion"). Indeed, if one's opinions etc. were simply 'subjective' inclinations or decisions in which there's nothing for others to understand or question, they would be a kind of objective fact about one, like the size of one's feet. On the standard view, opinions are 'subjectively objective' in this sense, yet people are supposedly 'entitled' to have them and should be 'respected' when expressing them. What can this mean? Should I be respected for having size 10 shoes? And if you can never question my opinion or ask me what I mean, only 
'respect' it (since I'm 'entitled' to it), what's the point of my telling you what I think at all? Also: how do we ourselves know what we think? As Wittgenstein reminds us in his reflections on the fantasy of a 'private language' (PI: \$243 ff.), insofar as one is in principle unable to make sense to another, one is eo ipso unable to make sense to oneself.

If, then, 'post-truth' names a fantastical mindset where one feels 'entitled' to one's own facts, not just one's own opinions, its absurdity is a natural development of the absurdity already present in the idea of being 'entitled' to one's opinions, to a kind of 'truth for me'. If I'm 'entitled' to the opinion ' $\mathrm{X}$ ' regardless of whether I'm able to explain what I mean by ' $\mathrm{X}$ ', then I'm surely 'entitled' to believe that ' $\mathrm{Y}$ ' is a 'fact' even though I'm quite unable to explain how I could believe it. This kind of absurdity results from 'taking seriously' the metaphysical picture of all questions as divided into questions of either fact or opinion/value. That is, the picture cannot actually be applied in a way that would make sense. A central concern of Wittgenstein's is, of course, to show that this is how metaphysical pictures 'work', i.e., they don't really work. ${ }^{11}$ However, while the pictures are confused, their attraction is real to those who feel it, for it is connected to real-life difficulties and temptations, to the collective modes of being, the climates of fearful and wishful opinion which pervade our ways of thinking. As Wittgenstein indicates, precisely this connection is what gives philosophical problems depth, makes them difficult in a sense that isn't merely or primarily intellectual. ${ }^{12}$ The fundamental role given to the fact/value-distinction and the idea of being entitled to one's opinions aren't philosophical fancies disconnected from life, but defensive figures of interaction and thought commonly met with in public and private settings, and expressive of the very hostility to understanding discussed above.

'Respecting the other's right to their opinion' means not questioning them about it, not challenging them where they don't want one to, and one's own 'right' to one's opinions, feelings, etc. is appealed to precisely when one wants to shield oneself from challenge. I say

${ }^{11}$ Cf. Ms 130: 51 [in BEE]; Z: \275; PI: \§37-38, 51-52, 115-116, 131-132, and the 'private language'-discussion, $\ 243 \mathrm{ff}$., etc.

12 See Backström 2011 and 2013. If my characterisation sounds un-Wittgensteinian, consider, for example, PI: $\$ 111$ (depth), PO: 185 (collective confusions) and CV: 17 (non-intellectual difficulties). 
something; you respond critically or ask a question I feel unable to answer, and that - i.e., the very point where I would need to be questioned, where I'm instinctively aware that I don't really understand things as I wish I could and pretend to understand them - is when I say "Everyone has a right to their opinion/belief, and this is mine". Asserting such a 'right' has no place in discussions where people genuinely try to understand each other and the issues they address. In such discussions, if I cannot answer your question about what I claim to believe, I'll either give up my belief, since your question made me see there was something wrong with it, or I'll say "I don't know what to say, I'll have to think more about it; how about this..." etc. What I won't do is assert a 'right' not to be challenged. Everyone has opinions, beliefs and feelings, but what they really mean, what there is in them of truth or untruth, is something one has to ask oneself, and ask those one encounters. That is: one will ask, again and again, insofar as one longs to understand, to reach the other and to know oneself. 'Rights' don't come into this at all, but insofar as one feels this longing, one will address and listen to the person in front of one, whoever they may be. One won't think that there are some 'kinds' of people whom one doesn't have to listen to and can 'rightfully' exclude from the conversation.

The idea of 'freedom of opinion and expression' is, in part, a way of trying to ensure something like this kind of non-excluding attention to each person by way of a provision of rights. The problem is that one thus turns the matter into, or accepts that it has been turned into, a question of power (rights must be enforceable). And insofar as power, rights and entitlements are in play; insofar as that is how the interlocutors think of their discussion, it will be perverted, the more so the more dominating the power/rights-perspective becomes. This is illustrated by how freedom of speech is typically debated today, with some wishing to limit more strictly what may be said while those who would thereby be excluded from the conversation appeal to their 'right', in the name of free speech, to continue expressing, e.g., racist or sexist attitudes. There's seldom any reflection on the fact that speaking is meaningless when no one listens. This isn't about having a 
'duty' to listen corresponding to the 'right' to speak, but about actually wanting to understand the other. ${ }^{13}$

One has opinions only where one lacks, or wants to defend against, a clear understanding and personal relation to whatever the opinion concerns. Thus, if two tourists differ about the best way to get somewhere, a local may decide the question, saying "This isn't a matter of opinion; I know, I live here". More importantly, knowing another human being - not in the way a detective might, but as a friend does means that, in the most important respects, one doesn't have opinions about the other but, precisely, knows them (cf. Marcel 2002). Knowing truths about them isn't the main thing here, but relating to the other truthfully; wholeheartedly longing to know them, to reach them, to be and stay in contact - which includes the longing to re-establish contact, to open things up again whenever oneself and/or the other has reacted to a conflict by breaking contact, by withdrawing into self-pity, offended indignation or some other self-centred, destructive attitude. Insofar as we aren't in open contact but rather keep a wary distance to each other, we form all kinds of opinions about each other. For example: instead of asking you why you said something, what you meant by it, I instinctively respond by forming an opinion, say, to the effect that 'anyone who likes that kind of thing is a vulgar person'. Instead of addressing you, I assume a disdainful attitude. Or I respond by forming a 'positive' opinion, expressive of an equally instinctive sense of appreciative identification, a feeling that you're 'just like me', and in my wish to flatter you - and, 'incidentally', myself - by manifesting my appreciative identification, I refrain from saying anything that might upset the fantasised harmony of opinions.

Opinions aren't, typically, evaluatively neutral 'views of things', or something individuals simply 'have' independently of others. Rather, they are modes of expressing one's affiliation with certain groups, of affirming 'us' as 'good' and a contrasting 'them' as bad or indifferent. Generally speaking, our so-called 'personal' opinions are constellations of 'memes' floating around in the collective climate of opinion in which we're immersed, and in defending my 'right' to 'my' opinions, what I shield from challenge is my unthinking identification and belonging

13 See Weil (2005) for an insightful and problematic critique of the discourse of 'rights', including to 'free speech'. 
with this or that community of like-minded people, i.e., of people who refuse to ask questions at roughly the same points because they fear the same challenges. Wittgenstein's remark that the philosopher isn't (must strive not to be) "a citizen of any community of ideas" (Z: \455) should be read in this light. In a community of ideas, of opinions, we enter a kind of conspiracy to keep challenges at bay by repeating shared opinions and insisting on our 'right' to them against others. In this way, we close ourselves to those outside, who have different opinions - but also to ourselves, for our opinions are masks we wear in front of each other and ourselves, all the time telling ourselves that this is really what we think, these are our real faces, yet always careful not to try whether the mask might actually come off. This illustrates how the longing for, and the difficulties of knowing oneself in the moral-existential sense are inseparable from the longing for, and the difficulties of, knowing others.

The hostility to understanding, to truthful relations between us, is manifest primarily in systematic and successful operations of avoidance, and the more successful they are, the less noticeable they will be - to those who take part in them. However, when people are forced face-to-face with the question of understanding, when it is no longer possible to smoothly avoid it, things turn nasty. The trial of Socrates is a classic illustration of this. Socrates' accusers were, as he explains, inspired by a collective hostility against him, rooted in the way his practice of questioning people - which precisely didn't 'respect' their opinions but aimed to sift truth from untruth in them threatened their comfortable sense that they knew what they thought and who they were. He deprived them of the opinions by which they supposedly lived by revealing that they didn't actually live by them and that they couldn't even coherently explain what 'they' were. But insofar as people fearfully refused leaving the collective life of opinion and follow Socrates in examining their life, they responded by forming hostile opinions of him, built from the store of general and malicious opinions concerning philosophers already floating around in the Athenian collective consciousness. These opinions were as confused as any others, as Socrates easily showed in questioning his accusers at the trial, but that merely added to their hostile conviction of his guilt. (Conviction is merely an intensely held opinion, a defence against and 
ersatz for understanding; one insists that one is convinced precisely of what one cannot really make clear to oneself.)

Here, someone might object that I'm just repeating Socrates' (or Plato's) opinion of the background and stakes of the trial ${ }^{14}$; his accusers looked at it differently. This objection shows the hopelessness - and, from another angle, the secret aim and effectiveness - of the perspective in which everything related to understanding is reduced to opinions. It amounts to assuming a would-be spectator's view from which one can only note that A expresses one opinion and B another, and finding one of them 'truer' can only mean 'siding' with one against the other. Since no one can, supposedly, say where 'the truth' lies, it appears legitimate to remain comfortably aloof from a conflict in which it might be inconvenient, even dangerous to get involved, and from the challenging work of understanding that truthful involvement would entail. Or else, one throws oneself into the conflict in a partisan spirit, where one dismisses questions of understanding as irrelevant and even irresponsible, since one's task, supposedly, is to help the side one has chosen ("Right or wrong, my country"). At this point, the idea of 'values' functions analogously to 'opinions'; 'values' are what moral understanding is misrepresented as and replaced by when conceived as a matter of moral 'opinions', whether personal or shared within a group or culture. ${ }^{15}$ We have our values and they theirs, just as I have my opinions and you have yours; there's essentially (supposedly) nothing to understand here, one can only note the differences, and, if one finds one cannot 'accept' or 'tolerate' the others' values, fight it out. This, conveniently enough, shields 'us' from critique both of our values and of the violence with which we may 'defend' them and impose them on others, for if there's nothing to decide who is really right, then what else is there but violence to resort to in the end?

But, it may be asked, isn't that simply how it is: people disagree violently about moral matters. They do. Note, however, that to the extent that there's moral conflict between people, conflict where one feels that the other's behaviour or claims are morally wrong or evil, this means (as discussed above) that at least one party represses, i.e.,

\footnotetext{
${ }^{14}$ See the Apology in Plato 1997.

${ }^{15}$ For critiques of the values-perspective, see Backström 2015; Backström and Nykänen 2016a and 2016b.
} 
disguises from themselves, the destructiveness of their own attitude. ${ }^{16}$ And this will include presenting everything as a matter of values/opinion ("We just see things differently"), or else misrepresenting the other's view as mere evaluative opinion, while selfdeceptively presenting one's own view as the truth. What can lend this perspective an appearance of plausibility is the fact that there's no morally neutral meta-perspective from which to decide where the truth actually lies. But the point is that this doesn't mean that there's no truth in moral matters, or that it is somehow essentially uncertain; it means that there's no morally unengaged way to know it. One cannot understand the conflict by standing aloof from it, nor, of course, by entering it in a partisan spirit. Rather, one must get involved in a truthful way, listening to and striving to understand everyone involved, including oneself; to understand how those involved relate to each other, what their (again, including one's own) actual motives and orientations are, not just how they can, by self-serving rhetoric and reasoning, be represented. The difficulty of this task isn't basically intellectual, but moral-existential; it is about daring to face oneself and others openly, without the defensive masks and armour of opinions, convictions and the other devices we use to block understanding. And 'reason' and 'logic' (arguing) are as useless here as 'introspection' (telling oneself what one feels/thinks) as long as one doesn't want to understand. As Wittgenstein notes, "When you bump against the limits of your own honesty, it is as though your thoughts get into a whirlpool, an infinite regress: You can say what you like, it takes you no further" (CV: 8).

\section{Philosophy's fateful choice: collective representation or interpersonal understanding?}

Collective conspiracies of 'understanding' exist because we need to obfuscate our own sense of our fearful destructiveness; we muddy the

${ }^{16}$ Couldn't there be simple, innocent misunderstanding on both sides? Well, is it innocent to falsely regard another's attitude as evil? If one's perception is false, this reveals evil in one's own way of regarding the other. Note that we're not discussing factual mistakes, say falsely believing that the medicine in a bottle is poison, but moral cases; cases involving one's attitude to others, say falsely and distrustfully imagining that someone wishes to poison you. Here, realising the truth is a moral awakening; "Forgive me! How could I think that you would ever...". 
waters of our own understanding with the fake intelligibility we collectively create for that purpose, pretending that we don't understand what we understand and understand what we don't understand. Standard philosophical conceptions of truth, meaning and ethics, however, aren't just ill-suited to register, but effectively function to hide, this dynamics between true and fake understanding. The dominant view today regards moral understanding as acquired through socialization, through mastering the web of evaluative concepts that constitutes the local "moral language" which serves as "a store of historically accumulated wisdom about what is a reason for what"; moral understanding is thus simply "a particular case of a general phenomenon: initiation into conceptual capacities" (McDowell 1996: 126; 84). This gives "the concept of representation [...] an essential role", insofar as (supposedly) only "our use of moral concepts to describe our own, and one another's, behaviour [...] endows that behaviour with moral meaning, and [...] brings it within the scope of the going moral 'grammar"' (Lovibond 1983: 63). This view, however, gives rise to an obvious problem with relativism, for who's to say which way of representing an action is right? And this is morally speaking crucial: were your remarks 'an innocent piece of fun' or rather a case of 'harassment', for example? The reply that communal consensus decides; that we collectively hold each other to common standards, doesn't solve but merely states the problem, for the 'moral language' as a whole - the way members of a community tend to speak and think, explicitly and implicitly, about moral matters - may be distorted in evil ways, and will be, as we've seen, insofar as the collective life of the speech community is marked by injustice.

For example, many now see sexualised joking of the kind that used to pass as 'innocent fun' as part of a culture of harassment and oppression of women. Are they right? In terms of 'moral languages' or 'conceptual schemes' (patterns of concept-use), one cannot even pose this question. Concepts aren't pre-carved into reality; rather, people carve up reality in different ways with the help of concepts and according to their various interests, which are in turn formed by these concepts (cf. Wittgenstein, PI: \$570). In a society organised around slavery, say, it is certainly of interest to the slaveholders that the slaves are kept in their place. This will show in the society's 'conceptual 
scheme', in the way slaves are talked about, and objecting to slavery implies objecting to slave-society's 'conceptuality', to their way of representing things. But on the level of conceptual schemes and modes of representation, how could one say that their scheme/mode is worse than any other? If one says they shouldn't represent things like that but like this, the matter is reduced to a simple struggle of power and preference, as we saw with regard to values-discourse (values are, or include, conceptualisations).

Reason won't decide anything here, insofar as reasoning means arguing about matters using the formal criteria and connections inscribed in the conceptual scheme shared (more or less) among the interlocutors, including such appeals to facts as are deemed relevant and drawing such conclusions as are deemed reasonable and true. It's no aberration, but a part of what 'reasonable opinion/judgement' means, that it for long solidly opposed the abolition of slavery, as it has opposed and will oppose every challenge to socially entrenched oppression and privilege, however obviously illegitimate and unreasonable this may appear to later times, when collective opinion and hence the sense of what's reasonable and obvious has changed. A direct measure of how reasonable a view appeared then is how unreasonable it appears now. Rationalist philosophers may say that 'reason itself' was always on the side of abolition and equal rights, even if people didn't see it and mistook unreason for reason. But if so, 'reason' is something that even the most reasonable people in a given society are generally unable to recognise on the very points where it would be most needed: where their society sanctions evil. Rather than trying to 'save' an in any case impotent reason, one should question the assumption of a direct connection between the distinctions good/evil and reasonable/unreasonable. The problem with evil isn't that it is irrational or unreasonable; the problem with evil is its evil, to put it in the tautological terms to which one is reduced in trying to say what shows itself, as early Wittgenstein might have said (cf. TLP: 4.1214.1212). One doesn't perceive evil - callousness, meanness, etc. - as a result of arguments, and if one starts reasoning about the wrongness of slavery, say, one has already conceded too much, insofar as one then 
admits, in principle, that the slaveholder might be right. If one doesn't admit that, one isn't really reasoning, merely rationalising.

To understand the role that 'reasoning' actually plays in the context of challenges to collectively sanctioned evil, one should rather note that when a woman in a traditionally patriarchal social context, say, demands the right to speak and be heard the same as a man, those who object perceive her demand as 'unreasonable' in a totally different sense from how they perceive the behaviour of someone who simply and genuinely shows a lack of reasoning ability in some practical or theoretical matter (think of the exasperation of trying to explain a simple technical operation to someone who just doesn't get it). The woman demanding her rights is immediately perceived as making an outrageous demand; she isn't perceived as a simpleton, nor as the baffling kind of person whose words others quite genuinely cannot understand, but as a scandalous threat to the social order. The response will vary depending on how strong her position is, i.e., how difficult silencing her is felt to be. In easier cases, she'll just be ridiculed; where this doesn't shut her up, shaming, ostracism and outright physical violence come into play. And the reasoning, the public and private debates, that ensue in connection with cases like this aren't disinterestedly intellectual exercises, but themselves part of the same socio-moralexistential struggle, pervaded by the same sense of scandal; the same acutely and personally felt threat to collective identities and privilege, and to the repressive, self-deceptive rationalisations that go with them. What takes place here isn't a juxtaposition of 'incommensurable conceptual schemes' which would make one party's claims literally unintelligible to the other, but an anguished, violent power-struggle over moral-existential realities, whose anguish and violence shows that those who oppose the oppressed person's demand to be heard understand her all too well; it is precisely what they understand but refuse to acknowledge that provokes their rage.

But, someone may object: regardless of what I've said, isn't all meaning and understanding unavoidably tied to languages, to conceptual schemes and the reasoning and judgements of truth these allow? In short, wasn't Plato right that "the manifold is seen with the eye, the idea with the mind, and the idea decides what each thing is" (Republic: 507b)? Isn't this also the basic insight Wittgenstein and others 
have formulated in terms of 'practices' and 'forms of life'? Don't "the shared practices into which we are socialized provide a background understanding of what counts as objects [...] and ultimately what counts as real", and so also of "what counts as human beings", so that only given this background understanding can we "direct our minds towards particular [...] people" (Dreyfus 1989: 42)? And if so, isn't any idea of the sort I have indicated about an interpersonal relationship and understanding between human beings, between ' $\mathrm{I}$ ' and 'you', not mediated by cultural normativity, bound to be illusory?

It might seem so, but this actually puts the cart before the horse. Far from language with its conceptuality being presupposed in one human being recognising another, the fact that we recognise, address and feel addressed by, one another is presupposed in the teaching of language, as in the induction into any shared practice. Child and adult already recognise and understand each other: the adult sees that the child is looking at something, is delighted or frightened by it; the child recognises that the adult is addressing her rather than just making noise, etc. This interpersonal understanding cannot be brought about by the use of signs (words) but must be there for child and adult to be able to engage in sign-use at all. This is actually later Wittgenstein's teaching too; as he says, this kind of mutual responsiveness, for example our responses to another's pain or joy, are "so many natural, instinctive kinds of behaviour towards other human beings, and our language is merely an auxiliary to, and further extension of, this relation" (Z: \545, emphases added). When I speak of interpersonal understanding, this is what I mean; our spontaneous responses to the good and evil we sense when we're warmed by another's smile or chilled by their callousness, say. While affective, these aren't blind reactions but modes of understanding; one perceives and opens oneself to the openness expressed in the other's smile, and is saddened by the way they, in their callousness, shut themselves to oneself and others. These aren't 'merely psychological' responses irrelevant to the 'ideal' demands of morality; 
if we weren't touched and moved in these ways, if we lacked the understanding manifest in them, there wouldn't be any morality at all. ${ }^{17}$

This isn't to deny the pervasive, and destructive, role played by concepts and representations in moral life; it is precisely through these that the difference between understanding and 'understanding' is both instituted and obfuscated. All formal moral relations of authority, rights, duties, etc., which define human beings as belonging in different conventional, moral-legal categories (man, woman, slave, free, etc.), are strictly speaking ideal, conceptually mediated relations, but they are used for deforming real human relationships. As Plato noted, it is only because of the relationship of the 'idea' of mastery to that of slavery that there can be masters and slaves (Parmenides:133d-e). But the idea of the slave isn't flogged, the real slave of flesh and blood is; it is his or her body and soul that is lacerated, just as it is the master's soul that suffers what souls suffer from treating another human being thus. Human beings aren't like ink-marks on a page that one can form, draw and redraw as one sees fit, according to whatever system of writing one happens to know and prefer, without the ink itself making any objection or awakening any objection in oneself to how one handles it. There's always-already a relationship in place between us that gives the imposition of various conceptual and normative schemes both their felt urgency (one feels threatened by certain people and anxiously tries to shut them up, say) and their ineliminable difficulty (shutting someone up isn't a formal operation, but gives one bad conscience, makes one ill at ease, even if one also has a relieved sense of protecting oneself).

It is because the relationship between us is unavoidable and cannot simply be deleted that one must, in doing evil, repress one's understanding (that is, conscience). Repression is an attempt to escape the inescapable, like running to get away from one's own shadow. Truth in the morally pregnant sense becomes an issue, and the distinction between understanding and 'understanding' comes to have a meaning, precisely in this gap that opens between the felt-andunderstood moral relationship between particular human beings that is always-already there, and the ideal normativity of conceptual schemes

17 See, further, Backström 2017 from which this paragraph is reproduced, and on openness and morality more broadly, Backström 2007. 
and collective organisation that regiments and represses that understanding. What is 'true' or 'reasonable' from the latter perspective, i.e., in terms of public discourse, indeed depends on how things are or can, within the discourse, be represented. The public character of a discourse consists precisely in making representability into the criterion of sense - which means that one may also speak in the public mode alone to oneself in the inner dialogue of thinking, insofar as one's own attitude is a public, representational one. In moralexistential (as opposed to purely practical or intellectual) contexts, understanding is replaced with 'understanding' to the extent that representability becomes the criterion of sense - or one could say that the basic move is introducing a criterion of sense, instead of simply searching for and making sense, one person to the other, ' $\mathrm{I}$ ' to 'you'. Wittgenstein rightly insists that a "radical break" with the view that language is essentially representational - a move from the first/thirdperson representational to the second person relational, one might say - is prerequisite for clearing up the deepest philosophical confusions (PI: §304). ${ }^{18}$

In focusing on representability, one depersonalises oneself, brackets (represses) the question whether I do or don't actually understand you, here and now, and instead allows the play of representations, the way in which they can and cannot, according to shared collective 'understandings', formally be arranged and argued for, decide what one declares understandable or not. If I genuinely want to understand you, the question isn't, for example, whether you said something formally characterisable as 'politically incorrect', but what you meant by your words, how you related to me (and perhaps to others)

18 Cf. Backström 2017, Nykänen 2014b and 2018. - My critical remarks about criteria may sound un-Wittgensteinian, as Wittgenstein is constantly talking about criteria of meaning. But he actually underlines that there aren't criteria for one person's understanding of another in the same way as in factual and intellectual contexts. Thus he notes that one can be "quite certain" of what another feels "and yet accept no criterion as certain"; for instance, I might see that you're glad, yet "I cannot describe my observations to a third person and - even if he trusts them - thereby convince him of the genuineness of that gladness", and this is connected to the fact that "one must 'know' someone in order to be able to judge what meaning is to be attributed to one of his expressions of feeling, and yet [...] one cannot describe what it is that one knows about him" (LWPP II: 86-7; 89-90). Note that this isn't pernicious 'subjectivism', for Wittgenstein is talking about the way two people are in contact, open to each other. This is the basic sense of 'know' in interpersonal understanding; it is neither 'subjective' nor 'objective'. 
in speaking them. Was there, say, contempt, meanness, fear, anguish, desire, interest, longing to reach me, in your voice, in your approach to me? This question cannot be decided by your unilateral declaration, for understanding isn't decided by anyone, or by your introspective report of what you subjectively 'meant', for insofar as self-deceptive repression is involved, what you tell yourself you mean and feel is false. But it also isn't a formal question about how your words can be publicly 'represented'. Rather, it is a question of conscience, for you and for me. In my case: How do I understand you, what is my sense of and connection to you? If I say you were being mean, I'm of course applying the concept 'meanness', which I learnt in learning our common language, but the most extensive knowledge of moral concepts wouldn't allow me to perceive your meanness if I didn't have a sense of you in your actual relation to me, if you didn't touch and move me (through your words, gestures, etc.). And whether my claim that you were mean is true depends on whether my relation to you and myself is truthful; it may also be, say, that you were harshly critical but spoke in a truthful spirit which I, however, found challenging and so, with self-deceptive, self-pitying indignation 'heard' as 'meanness'.

Referring to 'truth' as that concept is usually understood in philosophy misses what is at stake here and what is, simultaneously, at the heart of the problematic of 'post-truth'. Coherence and correspondence theories of truth are just two options within the same representationalist paradigm. The first focuses on how statements (conceptualisations, representations) can be made to formally cohere with one another; the second on how statements can be made formally to correspond to states of affairs, to facts (equally formally defined as the facts they are through their being picked out by the formally defined statements). That neither coherence nor correspondence prevents one from speaking falsely in the morally important sense is clear: people spin quite coherent and convincing tales - or 'narratives' as they are, often in an uncritically positive tone, called in contemporary discussions - in the service of all kinds of self-deceptions, and one can carefully keep from stating anything formally false ("not corresponding to the facts') while grievously misleading oneself and one's interlocutors, for example through the false light, perhaps self-pitying or moralistically judgemental, in which one puts the facts one cites. 
From the I-you-perspective, the essential point is the truthfulness of the contact between interlocutors, not the discourse considered formally ('as such'). When our contact is truthful, we may within this truthfulness realise that something that was said doesn't correspond to the facts or cohere with something else, and this will of course be a problem insofar as it renders what we mean to say unclear. But the point is that there's no neutral, collectively accessible and certifiable way - i.e., one that would be 'established' outside the relationship of the speakers - of truthfully judging coherence or correspondence, not to speak of perceiving the quality, e.g., the honesty or irony, of the speakers' attitudes, which isn't about coherence or correspondence at all.

Again, we see how truth in the interpersonal, morally crucial sense is independent of, and invisible to, 'reason', whether traditionally conceived as a human 'faculty', or 'socialised-naturalised' as the normativity of public rational discourse with its various claims to truth and validity. As Wittgenstein said, in a statement that to the rationalist will seem irresponsibly irrational: where moral-existential truth is at stake, 'reasoning' and 'justifications' are only "chatter" (Waismann 1965: 13; cf. Backström 2017). The real dialogue that this chatter tries to drown out takes place between 'I' and 'you', and as Hannes Nykänen shows (2014b; 2018), the radical core of Wittgenstein's philosophical 'methodology' is precisely his endeavour to get his reader/interlocutor to consider what it would actually be like to address their claims/questions to someone. The 'doubts' and the corresponding 'need for justifications' that from the philosopher's normal, essentially public-representational perspective appear 'valid' and 'inescapable' may then reveal a very different aspect. "Just try - in a real case - to doubt someone else's fear or pain" (PI: \$303) may sound like the 'common sense philosopher's' platitudinous objection "But we don't actually doubt people's pains", but it is completely different, for Wittgenstein isn't speaking from a collective perspective ("Look, we all know that ..."); on the contrary, he is urging you to free your thought from that perspective, to make the case real by considering the other person afraid or in pain, turning to him or her and now 'doubting'. By contrast, from the collective perspective, where representability decides sense, there's indeed no limit in principle to what may be 'entertained', from 
slavery to 'the problem of other minds'. This juxtaposition of madness in philosophy and politics isn't 'guilt by association', but a matter of pointing out the common 'logic' of a way of thinking.

\section{The moral of the story}

What, then, about 'post-truth' as a socio-political phenomenon? How should we deal with the threat it poses - which I agree is real - in the form of an atmosphere of generalised distrust and contempt for the old authorities (respectable news media, science, etc.) which allows the most brazenly and perniciously manipulative style of public address to appear as just 'a different point of view, as legitimate as any other'? I have no political recommendations to offer; no advice, that is, on how one should address the public, whether to rouse the crowd or speak to the sensibilities and proud sense of responsibility of the reasonable and respectable. I don't claim that we, or any culture, could do without public speech and public claims to truth, but I have tried to bring out the essential ambivalence, regardless of the de facto necessity, of such public claims, insofar as they are part of a collective mode of life premised on hostile repression of interpersonal understanding. At bottom, 'post-truth' and 'truth', in their very opposition, share a common collective-representational 'logic' - one created by the repression of I-you-understanding. As Wittgenstein underlines, understanding in a real, philosophical sense isn't achieved by choosing sides, 'for' or 'against', but rather by changing the whole 'game', the perspective from which one looks at things (cf. PI: \$S\$304-309). Collectivity, however, is constituted by an oppositional dynamic, 'us' against 'them', on all levels, from lynching mobs to 'communities of ideas', all with their particular claims to 'truth', if only in the form of their 'opinions'. The crucial thing - crucial also, although not primarily, for one's ability to judge the sense and real effectiveness of any public action one may undertake - is to struggle against the befogging of one's own understanding, and this means, of one's own way of relating to others, through conspiratorial collective 'understandings' and 'oppositions'. The first step of this struggle is to realise how thick is the fog; realising that one is lost. "A philosophical problem has the form: 'I don't know my way about”' (PI: \$123). 


\section{References}

Anderson, C., 2008. "The end of theory: The data deluge makes the scientific method obsolete". Wired magazine, June 23 2008. Available at: http://archive.wired.com/science/discoveries/magazine/16$07 / \mathrm{pb}$ theory/ [accessed February 14 2018].

Arendt, H., 1973. The Origins of Totalitarianism. New edition with added prefaces. New York: Harcourt Brace \& Company.

Backström, J., 2007. The Fear of Openness: An Essay on Friendship and the Roots of Morality. Åbo: Åbo Akademi University Press.

Backström, J., 2011. "Wittgenstein and the moral dimension of philosophical problems". In: O. Kuusela and M. McGinn, eds., The Oxford Handbook of Wittgenstein. Oxford: Oxford University Press, 729-752.

Backström, J., 2013. "Wittgenstein, follower of Freud”. In: Y. Gustafsson, C. Kronqvist and H. Nykänen, eds., Ethics and the Philosophy of Culture: Wittgensteinian Approaches. Newcastle upon Tyne: Cambridge Scholars Publishing, 212-244.

Backström, J., 2014a. "Fearful fantasies: Sexuality as a response to love". The Scandinavian Psychoanalytic Review 37, 48-59.

Backström, J., 2014b. "Touchy subjects: The theme of repression in Freud and Wittgenstein". European Journal of Psychoanalysis 2/2014.

Backström, J., 2015. "Of dictators and green-grocers: On the repressive grammar of values-discourse". Ethical Perspectives 22, 39-67.

Backström, J., 2017. "From nonsense to openness - Wittgenstein on moral sense". In: E. Dain and R. Agam-Segal, eds., Wittgenstein's Moral Thought. New York: Routledge, 247-275.

Backström, J., 2019. "Hiding from love: The repressed insight in Freud's account of morality". In: R. Gipps and M. Lacewing, eds., The Oxford Handbook of Philosophy and Psychoanalysis. Oxford: Oxford University Press, 595-616.

Backström, J. and Nykänen, H., 2016a. "Collectivity, evil and the dynamics of moral value". Journal of Evaluation in Clinical Practice 22, 466-476.

Backström, J. and Nykänen, H., 2016b. "Ethics: the perfect mix? Response to Buetow". Journal of Evaluation in Clinical Practice 22, 479-482.

Boag, S., 2012. Freudian Repression, the Unconscious, and the Dynamics of Inbibition. London: Karnac.

Bourdieu, P., 1977. Outline of a Theory of Practice, trans. R. Nice. Cambridge: Cambridge University Press.

Dreyfus, H. L., 1989. “Alternative Philosophical Conceptualizations of Psychopathology”. In: H. A. Durfee and D. F. T. Rodier, eds., 
Phenomenology and Beyond: The Self and Its Language. Contributions to Phenomenology, Vol. 3. Kluwer Academic Publishers, 41-50.

Ellul, J., 1975. The New Demons, trans. C. E. Hopkin. New York: Seabury Press. Girard, R., 2001. I See Satan Fall Like Lightning, trans. J. Williams. Maryknoll, NY: Orbis Books.

Klemperer, V., 2006 [1957]. The Language of the Third Reich. London: Continuum. Lovibond, S., 1983. Realism and Imagination in Ethics. Minneapolis: University of Minnesota Press.

Marcel, G., 2002. "From opinion to faith". In: G. Marcel, Creative Fidelity, trans. R. Rosthal. New York: Fordham University Press, 120-139.

McDowell, J., 1996. Mind and World - With a New Introduction. Cambridge, Mass.: Harvard University Press.

McMurtry, J., 1999. The Cancer Stage of Capitalism. London: Pluto Press.

Nietzsche, F., 1956 [1888]. The Genealogy of Morals, in F. Nietzsche, The Birth of Tragedy; and, The Genealogy of Morals, trans. Francis Golffing. New York: Doubleday.

Nykänen, H., 2002. The T', the 'You' and the Soul: An Ethics of Conscience. Åbo: Åbo Akademi University Press.

Nykänen, H., 2005. "Heidegger's Conscience”. Sats - Nordic Journal of Philosophy $6,40-65$.

Nykänen, H., 2009. Samvetet och det dolda - om kärlek och kollektivitet [Conscience and the hidden: On love and collectivity]. Ludvika: Dualis.

Nykänen, H., 2014a. "Conscience and collective pressure". Philosophy, Psychiatry, \& Psychology 21, 51-65.

Nykänen, H., 2014b. "Freud's Dangerous Pupil". European Journal of Psychoanalysis [online]. Available at: http://www.journalpsychoanalysis.eu/freuds-dangerous-pupil/ [accessed 7 May 2019].

Nykänen, H., 2015. "Repression and Moral Reasoning: An Outline of a New Approach in Ethical Understanding". Sats - Nordic Journal of Philosophy 16, 49-66.

Nykänen, H., 2018. "Wittgenstein's Radical Ethics". European Journal of Psychoanalysis [online]. Available at: http://www.journalpsychoanalysis.eu/wittgensteins-radical-ethics/ [accessed 7 May 2019].

Plato, 1997. Complete Works. Ed. John M. Cooper. Indianapolis: Hackett. Rabin, N., 2006. "Interview: Stephen Colbert" [online]. A.V. Club, 25 January 2006. Available at: http://www.avclub.com/article/stephen-colbert13970 [accessed 8 May 2019].

Rowbotham, M., 2009. The Grip of Death: A Study of Modern Money, Debt Slavery and Destructive Economics, $4^{\text {th }}$ ed. Charlbury: Jon Carpenter.

Shaikh, A., 2016. Capitalism: Competition, Conflict, Crises. Oxford: Oxford University Press.

Symington, N., 2004. The Blind Man Sees: Freud's Awakening and Other Essays. London: Karnac. 
Thucydides, 2008. The History of the Peloponnesian War, trans. Richard Crawley. Auckland: The Floating Press.

Waismann, F., 1965. "Notes on Talks with Wittgenstein". Philosophical Review 74, $12-16$.

Weil, S., 2005. "Human Personality", trans. R. Rhees. In: Siân Miles, ed., Simone Weil: An Anthology. London: Penguin, 69-98.

Wittgenstein, L., 1951. Tractatus Logico-Philosophicus, trans. C.K. Ogden. London: Routledge \& Kegan Paul. (TLP)

Wittgenstein, L., 1958. Philosophical Investigations, trans. G.E.M. Anscombe.

Oxford: Blackwell. (PI)

Wittgenstein, L., 1969. The Blue and The Brown Books. $2^{\text {nd }}$ ed. Oxford: Blackwell. (BB)

Wittgenstein, L., 1980. Culture and Value ed. G.H. von Wright in collaboration with H. Nyman, trans. P. Winch. Oxford: Blackwell. (CV)

Wittgenstein, L., 1989. Zettel, ed. G.E.M. Anscombe and G.H. von Wright, trans. G.E.M. Anscombe. Oxford: Blackwell. (Z)

Wittgenstein, L., 1992. Last Writings on the Philosophy of Psychology, Vol II, ed. G.H. von Wright and H. Nyman, trans. C.G. Luckhardt and M. Aue. Oxford: Blackwell. (LWPP II)

Wittgenstein, L., 1999. Philosophical Occasions, ed. J. C. Klagge and A. Nordman. Indianapolis: Hackett. (PO)

Wittgenstein, L., 2000. Wittgenstein's Nachlass: The Bergen Electronic Edition, ed. by the Wittgenstein Archives at the University of Bergen. Oxford: Oxford University Press. (BEE)

Yuran, N., 2014. What Money Wants: An Economy of Desire. Stanford, CA: Stanford University Press.

\section{Biographical Note}

Joel Backström, Ph.D., is researcher in philosophy at the University of Helsinki, where he also teaches philosophy. He is the author of The fear of openness: An essay on friendship and the roots of morality (AAUP, 2007) and coeditor of Moral Foundations of Philosophy of Mind (Palgrave, 2019). He has published articles and book-chapters on ethics, on Wittgenstein and on the philosophical dimensions of Freud's thought, including contributions to the Oxford Handbook on Wittgenstein (2011) and the Oxford Handbook on Philosophy and Psychoanalysis (2018). 